\title{
Determinants of grassland primary production in seasonally-dry silvopastoral systems in Central America
}

\author{
G. M. Rusch • P. C. Zapata - F. Casanoves • \\ P. Casals $\cdot$ M. Ibrahim $\cdot$ F. DeClerck
}

Received: 26 December 2013/ Accepted: 15 May 2014/Published online: 3 June 2014

(C) The Author(s) 2014. This article is published with open access at Springerlink.com

\begin{abstract}
Grassland primary productivity is the function that underpins the majority of the fodder production in cattle-rearing silvopastoral farms. Hence, understanding the factors that determine grassland productivity is critical for the design and management of silvpastoral systems. We studied the effect of two factors with documented impact on grassland productivity in seasonally dry silvopastures of Nicaragua, rainfall and trees. We assessed the effects of three species that differed in crown size and phenology, one evergreen, Cassia grandis, and two deciduous species, Guazuma ulmifolia and Tabebuia rosea. Overall, grassland ANPP had a quadratic response to rainfall, with a decline at high rainfall that coincided with peak standing biomass and grassland cover. Trees had a predominately negative effect
\end{abstract}

Electronic supplementary material The online version of this article (doi:10.1007/s10457-014-9711-8) contains supplementary material, which is available to authorized users.

G. M. Rusch ( $\square)$

Norwegian Institute for Nature Research (NINA), Trondheim, Norway

e-mail: graciela.rusch@nina.no

P. C. Zapata - F. Casanoves - M. Ibrahim - F. DeClerck Center for Tropical Agriculture Research and Education (CATIE), Turrialba, Costa Rica

P. C. Zapata

Universidad de Ciencias Aplicadas y Ambientales (U.D.C.A), Bogotá, Colombia on grassland productivity, and the effect was concentrated in the rainy season at peak productivity. The effect of the trees corresponded with the tree crown area, but not with crown density. Trees reduced the standing biomass of graminoids and increased forb biomass; thus, the effect of trees on grassland ANPP appears in part to respond to changes in grassland composition. We also found higher levels of soil moisture content below the tree canopy, particularly at the peak of the rainy season when soils tend to become waterlogged. The evergreen species, $C$. grandis, affected grassland ANPP more strongly than the deciduous species.

Keywords Grassland-tree interactions . Primary productivity $\cdot$ Rainfall $\cdot$ Tree crown traits

\author{
P. Casals \\ Centre Tecnològic Forestal de Catalunya (CTFC), Lleida, \\ Spain
M. Ibrahim (IICA), City of Belmopan, Belize
F. DeClerck
Agrobiodiversity and Ecosytem Services Program, \\ Inter-American Institute for Cooperation in Agriculture \\ Bioversity International, Montpellier, France
}




\section{Introduction}

Grassland primary productivity is the function that underpins the majority of the fodder production in cattle-rearing silvopastoral farms. Hence, understanding the factors that determine grassland productivity is critical for the design and management of silvpastoral systems. In seasonally-dry tropical climates, monthly rainfall is an important determinant of net primary productivity (Ospina et al. 2012), but studies that have evaluated this feature in silvopasture grasslands of Central America are few, and it is also not well known how rainfall interacts with the tree canopy in determining levels of grassland productivity in these systems.

In addition to the physical factors, trees in pastures can affect grassland growth directly through competition for resources and indirectly by setting the environment for understorey growth (Fernández et al. 2007). Therefore, knowledge about the outcome of tree-pasture interactions is necessary to maximize the multiple functions provided by well-managed silvopastoral systems. Trees and shrubs can enhance biomass production and the nutrient content of the grassland (Belsky et al. 1993). These responses are likely associated with the higher mineral and organic matter contents found under the trees compared to the open grassland (Casals et al. 2013) that result from litterfall and wet deposition (Scholes and Archer 1997). In addition to the impact on soil nutrient status, trees can decrease water stress and reduce evapotranspiration (Joffre and Rambal 1993), improve the water balance in the soil (Espeleta et al. 2004), and may further increase water availability for grassland plants through hydraulic lift (Ludwig et al. 2004). However, despite these positive effects of trees on the belowcanopy environment, competition between trees and the herbaceous vegetation can be severe and outweigh the facilitation effects (Ludwig et al. 2004).

The balance between positive and negative effects of trees on the pasture can be the result of the impact of the tree in interaction with the environment. Ecological theory predicts that the relative importance of facilitation and competition between woody plants and herbs is a function of environmental harshness, with a higher facilitation effect in more extreme environments and a predominance of competition under more benign conditions (Dohn et al. 2013), the "abiotic stress hypothesis" (Bertness and Hacker
1994). In seasonal climates, shifts in the degree of stress occur in time and, consequently, one could expect a shift in the nature of the tree-grassland interaction between seasons (Scholes and Archer 1997) by which trees would promote grassland production when water is limiting, and decrease it when conditions for growth are favorable.

Light interception is a critical mechanism through which trees determine the conditions of growth for grassland plants. However, there is large variability in the magnitude of shading among tree species depending on the crown size, density (Sotelo Reyes 2012) and phenology. Also, the effect of shading by the trees on grassland productivity can be mediated by changes in the relative composition of grassland functional groups (Belsky et al. 1993), for instance by promoting grassland species with higher shade tolerance, and different eco-physiological requirements and performance (Nordenstahl et al. 2011).

In this study, we focused on the seasonal changes in aboveground net primary productivity (ANPP) of the grassland, and asked the following specific questions: (1) To what extent does rainfall and trees determine grassland above-ground net primary productivity (ANPP) in seasonally-dry silvopastoral systems in Central America? (2) Do trees have a predominantly positive or negative effect on grassland ANPP, and does the direction of this effect change with the seasons, with more positive effects in the dry- and more negative effects in the rainy season?; (3) Does the effect of the trees correspond with different tree crown traits (crown density and size, and phenology?; and (4) Are the tree effects on the grassland related to the impact of the tree on soil water content and grassland composition? The effect of four common silvopastoral trees on the soil chemical properties was assessed in a parallel study (Casals et al. 2013).

\section{Methods}

The study area

The study was conducted in the Río Grande de Matagalpa watershed in Central Nicaragua $\left(12^{\circ} 31-13^{\circ} 20^{\prime} \mathrm{N} ; 84^{\circ} 45-86^{\circ} 15^{\prime} \mathrm{W}\right)$, in the counties of Muy Muy and Matiguás, within an altitudinal range of 200-400 m. The climate is strongly seasonal, as the rainfall recorded between November/December and 
April/May is usually less than $10 \%$ of the average annual rainfall (1532.8 mm, 1970-2010) for the meteorological station at Muy Muy, while the annual mean air temperature is $24.5^{\circ} \mathrm{C}$ (INETER 2011). The topography is undulating, with slopes between 5 and $45 \%$. The dominant soil type in the studied sites was a grayish to black Vertisol, with high organic matter content in the upper horizons $(8 \%)$. The natural vegetation of the region corresponds to a transitional tropical sub-humid forest with semi-deciduous vegetation, and is referred to as a seasonally dry tropical forest (Ospina et al. 2012). The land-units in the study were semi-natural grasslands with scattered trees. These grasslands are spontaneous vegetation that grow after forest clearing, or on fallow land, and which are maintained by grazing and weed control (Ospina et al. 2012). The predominant land-use is livestock farming, with relatively homogeneous livestock management. The study was conducted during the period from March to July 2009 in three and five locations in the areas of Muy Muy and Matiguás, respectively.

\section{Sampling sites}

The measurements were conducted on five trees of each of the three species (see "Tree species" section below) in the study. We selected the sites according to the following criteria to minimize between-site variability: the sampling sites were located in small- to medium-sized farms (smaller than $100 \mathrm{ha}$ ), and they had not been ploughed or burnt at least for the past 10 years. The trees were located approximately $30 \mathrm{~m}$ from its nearest neighbor to avoid any overlap of the area influenced by the trees in the sampling.

\section{Rainfall data}

Rain gauges were located in each of the four areas in the study (Guiligüas, Maizama, El Jobo and Río Bulbul), but not farther than $500 \mathrm{~m}$ from the sampling site. Rainfall data were obtained weekly during the period between April and July 2009 (Online Appendix $1)$.

\section{Soil moisture}

The soil moisture content in the soil surface layer $(0-5 \mathrm{~cm})$ was assessed eight times during the period of the study from the dry season (April) to the rainy season (June-July). In each site and at each sampling occasion, four measurements were made under the tree and in the open grassland. In the dry season, volumetric soil moisture content measurements were conducted with a ThetaProbe soil moisture sensor (ML2x, Delta-T Devices 2008), though due to problems with the functioning of the instrument, soil moisture was estimated gravimetrically (Cassel and Nielsen 1986) during the rainy season. Four soil $(0-5 \mathrm{~cm})$ sub-samples were collected, lumped and homogenized. The samples (ca $200 \mathrm{~g}$ fresh weight) were dried in an oven at $70{ }^{\circ} \mathrm{C}$.

\section{Tree species}

We selected three tree species for this study (Guazuma ulmifolia, Tabebuia rosea, and Cassia grandis) because they are common in silvopastoral systems in the study area, and have contrasting functional traits (crown type and phenology) that we expected would affect understorey vegetation differently (House et al. 2003). Guazuma ulmifolia Lam. (Gúacimo, Sterculiaceae), is a deciduous tree with wide distribution, from Mexico to Argentina and is common in seasonally dry forests and in silvopastoral systems in Nicaragua. T. rosea (Bertol.) D.C. (Roble, Bignoniaceae) is a deciduous species in seasonally dry areas, but the length of the period without leaves can vary considerably (ICRAF 2012). The species is common in seasonally dry forests and is distributed from Mexico to the coast in Ecuador (Stevens et al. 2001) and is adapted to soils with limited drainage, as are the vertisols in the study area. C. grandis L. f. (Carao, Caesalpinioideae) is considered as semideciduous (Stevens et al. 2001) although it maintains a high crown density in the dry season in the study area (ca $80 \%$ in February at the peak of the dry season $^{1}$ ). The characteristics of the trees in the study are presented in Table 1. G. ulmifolia and T. rosea exhibited clear crown deciduousness, whereas $C$. grandis trees maintained approximately two-thirds of the maximum crown density in the dry season (Table 1).

\footnotetext{
$\overline{1}$ Source: FUNCiTREE project database.
} 
Table 1 Whole tree and crown characteristics of the tree species in the study

\begin{tabular}{lcclll}
\hline Species & DBH $(\mathrm{cm})$ & Tree height $(\mathrm{m})$ & Crown area $\left(\mathrm{m}^{2}\right)$ & Crown density dry season $(\%)$ & Crown density rainy season $(\%)$ \\
\hline C. grandis & $45.2(35-55)$ & $12.4(9-16)$ & $231.3(149-328)$ & $42.5(25-60)$ & $67.3(61-80)$ \\
G. ulmifolia & $35.2(29-55)$ & $7.6(6-9)$ & $116.2(76-185)$ & $16.5(15-22)$ & $48.1(34-58)$ \\
T. rosea & $35.1(28-41)$ & $11.2(9-13)$ & $129.1(74-165)$ & $12.2(7-20)$ & $48.4(29-67)$ \\
\hline
\end{tabular}

Average values and ranges (in brackets). Dry- and rainy season measurements correspond to March-April and May-July, respectively

Crown density and area measurements

We assessed tree crown density using a densiometer every 30 days during the period from March to July 2009. Crown density at a particular time was calculated as the average of the density in four sectors under the tree crown, while the crown area was calculated based on the average of two perpendicular diameters, which were measured using a tape measure.

Grassland biomass sampling and ANPP calculation

The sampling area under the tree was determined by estimating an average area of shading using the shade projection software, ShadeMotion (Quesada et al. 2007). A rectangular area was delimited (16 and $12 \mathrm{~m}$ in $\mathrm{E}-\mathrm{W}$ and $\mathrm{N}-\mathrm{S}$ direction, respectively, in total $192 \mathrm{~m}^{2}$ ). The biomass samples were collected within this area, excluding a $2 \times 2 \mathrm{~m}$ portion surrounding the tree trunk. For each tree, control samples were collected in an adjacent open grassland area of comparable size and with similar conditions of topography. A biomass sample consisted of four $50 \times 50 \mathrm{~cm}$ sub-samples of green and standing dead mass that were collected in each of 4 quadrants (NW-NE-SW-SE) within the sampling area, at each sampling occasion. The four sub-samples were lumped into one sample per individual tree and sampling occasion.

Biomass samples were collected four times during the study period, at the start $\left(\mathrm{T}_{0}\right)$ and the end $\left(\mathrm{T}_{1}\right)$ of 30-day-interval periods of cattle grazing exclusion from April (transition from dry to rainy season) to July (peak rainy season) in 2009. Grazing in the " $\mathrm{T}_{1}$ plots" was excluded using cages $(50 \times 50 \times 70 \mathrm{~cm})$ that were moved to a new sampling point after harvest. In order to reduce sample variability for the calculation of ANPP, we positioned, at each sampling period, pairs of $T_{0}$ and $T_{1}$ samples in points with similar standing biomass. The location of the plot pairs $\left(T_{0}\right.$ and $\mathrm{T}_{1}$ ) corresponding to each sampling period was randomized within each quadrant at the start of the study. Samples were cut $2 \mathrm{~cm}$ above the ground level, weighted and dried in the oven (at $70{ }^{\circ} \mathrm{C}$ ) until reaching a constant weight. In total, $24050 \times 50 \mathrm{~cm}$ samples were collected for each location (under the tree and in the open grassland, respectively, 480 in total).

The ANPP was estimated as the sum of the positive differences in green and standing dead mass collected at the start $\left(\mathrm{T}_{0}\right)$ and end $\left(\mathrm{T}_{1}\right)$ of each 30-day sampling period, and with a correction for senescence according to Sala and Austin (2000).

Green biomass samples were sorted into two plant groups: grasses and sedges (graminoids), and forbs (minimum of $5 \mathrm{~g}$ per group and sample) for the grassland composition analysis.

\section{Statistical methods}

To assess the regression function between ANPP and rainfall, we used General Mixed Models in order to account for the effects of species, position and their interactions with the regressors (rainfall and rainfall square). Time (season) was not included in the regression model because it significantly correlated with rainfall.

Since biomass sampling and soil moisture measures were repeated in time and variances did not fulfil homoscedasticity assumptions, we used Generalized Linear Mixed models that allow the modeling of variances and the analysis of correlated data (McCulloch 2006). Grassland ANPP was modelled as a response to "species" (paired samples below the tree and in open grassland associated with $C$. grandis, $G$. 


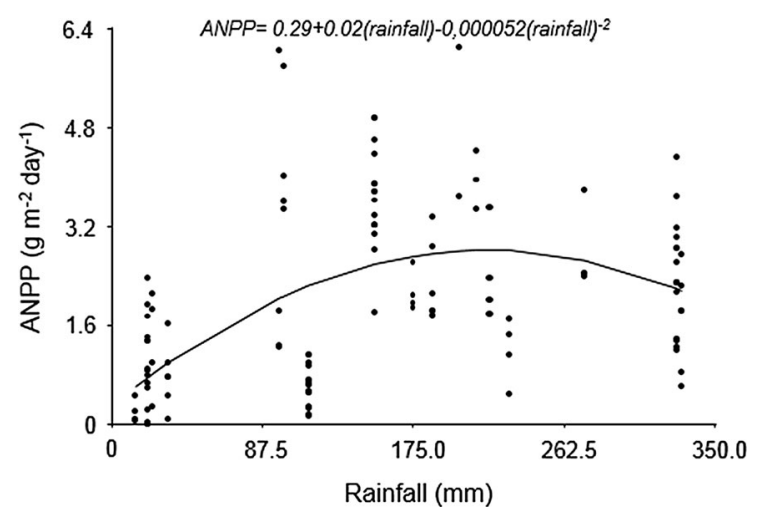

Fig. 1 Relationship between grassland daily average aboveground net primary production (ANPP) $\left(\mathrm{g} \mathrm{m}^{-2}\right.$ day $\left.^{-1}\right)$ and accumulated rainfall in a 30 days period $(\mathrm{mm})$

ulmifolia and T. rosea) and "position" (below the tree and open grassland) as main factors, "month" as random factor, and the two- and three-way interaction terms. Rainfall significantly explained the variation in ANPP (both the linear and the quadratic term of the ANPP-rainfall regression model were significant, Fig. 1), and therefore, the coefficients of the ANPPrainfall model were included as covariates to reduce the amount of unexplained variation in the mixed GLM model of ANPP. Soil moisture, percentage bare ground, and forb and graminoid biomass were modelled as a response to "species", "position" and "month" and the two- and three-way interaction terms.

The best-fitted models were selected with the Akaike's Information Criterion (AIC) and the Bayesian information criterion (BIC), and the normality assumption was tested with the Shapiro-Wilk test. To compare means, we used the Fisher's least significant difference test $(\mathrm{LSD})$ (significance level $=0.05$ ). The data were analyzed using the lme function of the nlme (Pinheiro et al. 2013; R Development Core Team 2013) and lme4 algorithms (Bates et al. 2013) in the R-package (Core Developing Team 2009) interfaced by InfoStat statistical software version 2012 (Di Rienzo et al. 2012).

To test whether the effect of the tree (positive or negative) shifted with the season due to changes in crown phenology and size, we calculated the Relative Interaction Index (RII) (Armas et al. 2004) based on the difference between ANPP under the tree and in the open grassland in the dry (March-April) and in the rainy season (May-July). RII is a dimensionless index

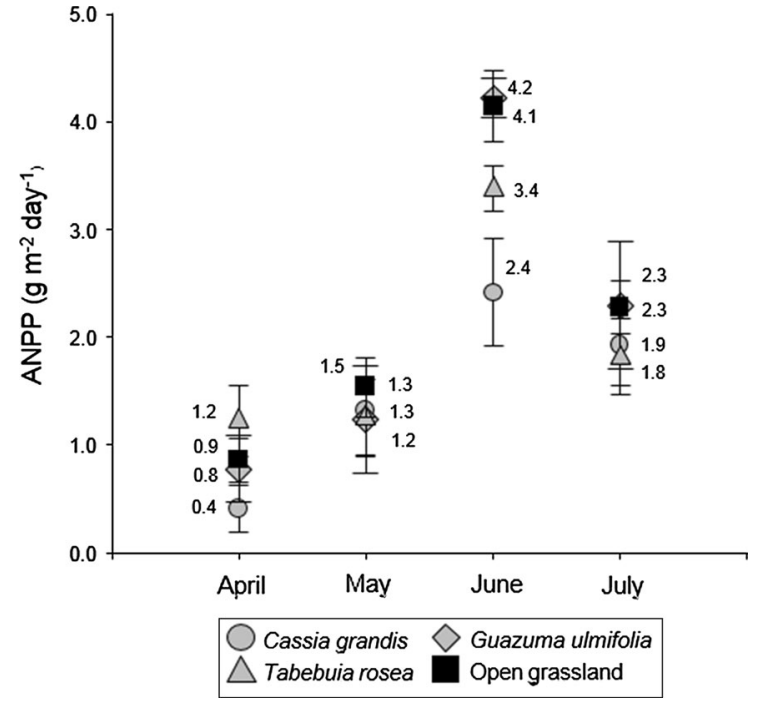

Fig. 2 Daily above-ground net primary production (ANPP) in the dry season (April/May) and in the rainy season (June/July) in grasslands under trees of $C$. grandis, G. ulmifolia and T. rosea and in open pasture (average of all sites). Grey circles, Cassia grandis; grey diamonds, Guazuma ulmifolia; grey triangles, Tabebuia rosea and black squares, open grassland

that ranges from -1 to +1 (from maximum negative to maximum positive effect). The relationships RII with the crown traits were tested with Pearson correlations, using the InfoStat package (Di Rienzo et al. 2012).

\section{Results}

Factors determining grassland ANPP

Grassland ANPP showed clear temporal differences ( $\mathrm{F}=52.04 ; P<0.0001$ ), being highest in June and lowest in April (Fig. 2). There were also clear temporal changes in the percentage of grassland cover (F $=37.05 ; P<0.0001$ ), with the proportion of bare ground being highest in April (23\%) and ground cover being almost complete in July (bare ground $0.3 \%$ ). The average grassland ANPP ranged from 2.0 to $2.4 \mathrm{~g} \mathrm{~m}^{-2}$ day $^{-1}$, with no differences among the locations associated with the three tree species (Fig. 3).

The accumulated rainfall in a 30-day-period had a significant effect on ANPP and showed a quadratic relationship $\left(\mathrm{T}_{\text {linear }}=5.89 ; P<0.0001 ; \mathrm{T}_{\text {quadr }}=\right.$ -4.84; $P<0.0001)$ : At the onset of the rains, grassland ANPP increased monotonically with 
rainfall, but declined when the accumulated rainfall exceeded $200 \mathrm{~mm}$ (Fig. 1). A marked decline in ANPP was also observed at the peak of the rainy season (July, Fig. 2).

Overall, ANPP was higher $(\mathrm{F}=3.97 ; P=0.0495)$ in the open grassland $\left(2.2 \mathrm{~g} \mathrm{~m}^{-2} \mathrm{day}^{-1}\right)$ than below the trees $\left(1.9 \mathrm{~g} \mathrm{~m}^{-2} \mathrm{day}^{-1}\right)$; amounting to ca $790 \mathrm{~g} \mathrm{~m}^{-2}$ and $680 \mathrm{~g} \mathrm{~m}^{-2}$ per year, respectively. Grassland ANPP under the trees was then $80 \%$ of ANPP of the open grassland. The effect of the evergreen species, $C$. grandis, was stronger than that of the deciduous species ("species" $\times$ "position" interaction $\mathrm{F}=2.21 ; P=0.06$; LSD Fisher test $P<0.05$, Fig. 3). The effect of the tree was most evident at the peak of the production period, in June, and also in this case, ANPP below C. grandis was lower than ANPP under the two deciduous species (LSD Fisher test $P<0.05$, Fig. 2). The interaction of "species," "position" and "month" was not significant $(\mathrm{F}=0.72 ; P=0.763)$, showing that there were no seasonal- or among species differences in the direction of the effect of the tree-whether positive or negative - on the grassland.

Crown properties and the effect on grassland ANPP

Tree crown density changed significantly with the season $(\mathrm{F}=4.94 ; P=0.0009)$ in all tree species, but there were marked species-specific differences. The highest crown density was observed in July in $C$. grandis, which also maintained a higher density in the

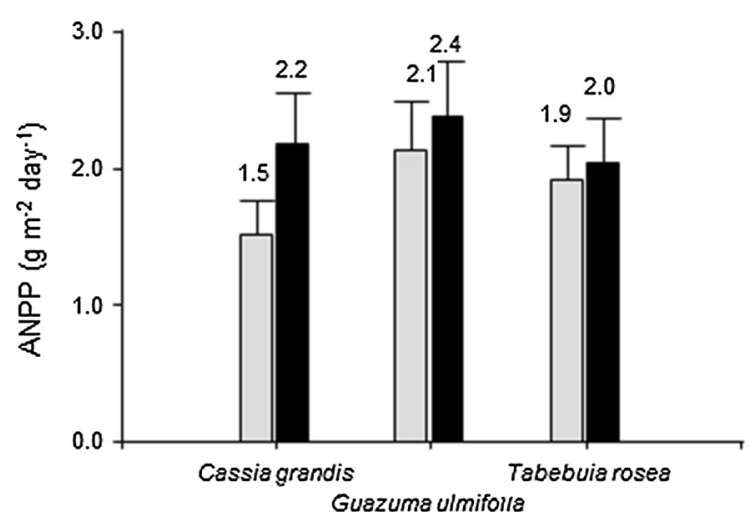

Fig. 3 Overall daily above ground primary production (ANPP) under trees of $C$. grandis, G. ulmifolia and T. rosea (grey bars) and in the corresponding open grassland area (black bars) dry- and the rainy season (Table 1). Overall, there was no correspondence between crown density and ANPP$\mathrm{RII}(\mathrm{F}=0.121, P=0.4101)$, and when testing the dryand rainy season independently, we found no correspondence between ANPP-RII in the dry season and crown density (Pearson $\mathrm{r}=-0.15, P=0.6030$ ) or crown area (Pearson $\mathrm{r}=-0.09, P=0.7395$ ) during this period. We also found no association between ANPP-RII in the wet season with crown density (Pearson $r=-0.38$, $P=0.1594)$, but a correspondence with crown area (Pearson $\mathrm{r}=-0.49, P=0.0659$ ).

Tree effects on grassland functional group composition

Graminoids comprised the majority of the standing biomass (Fig. 4a), and was higher $(\mathrm{F}=5.93$; $P=0.0167)$ in the open grassland $\left(127.55 \mathrm{~g} \mathrm{~m}^{-2}\right)$ than below the tree canopy $\left(105.56 \mathrm{~g} \mathrm{~m}^{-2}\right)$. There
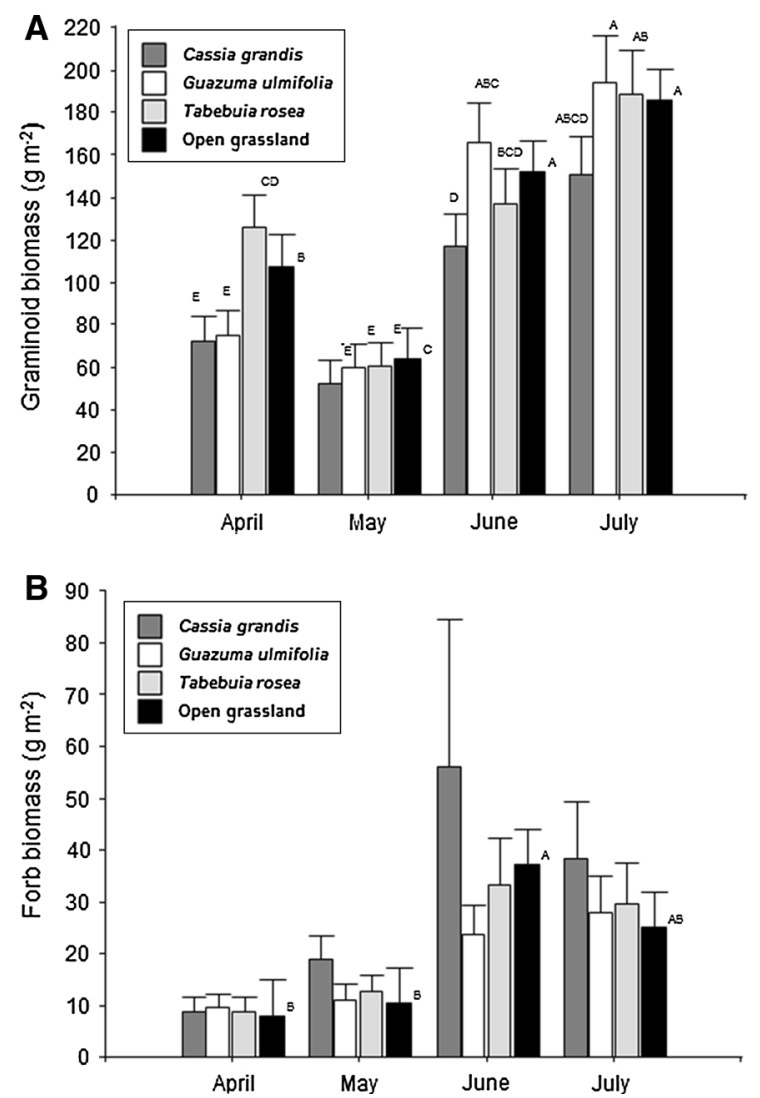

Fig. 4 Seasonal changes in standing mass of graminoids (a) and of forbs (b) in open grassland and under trees of $C$. grandis, G. ulmifolia and T. rosea 
were also differences in graminoid biomass among months $(\mathrm{F}=34.92 ; P<0.0001)$, with the highest values in July and the lowest in May (Fig. 4a). We found no differences among tree species in their effect on graminoid biomass ("species" $\times$ "position," $\mathrm{F}=0.58 ; P=0.5636$ ).

In the case of forbs, there were differences in standing biomass between months $(\mathrm{F}=7.85$; $P<0.0001$ ), with the highest biomass in June and the lowest in April (Fig. 5b). There was an overall positive effect of the tree on forb biomass $(\mathrm{F}=4.35$; $P=0.0395)$, but no different effects among the tree species ("species" $\times$ "position" interaction $\mathrm{F}=0.000087 ; P=0.999$ ).

Effect of the trees on soil water

The main factor determining differences in soil moisture was the time of the year $(\mathrm{F}=428.92$; $P=0.0001)$; soil water content increased steadily from the onset of the rains (Fig. 5). Trees had an effect on soil moisture content depending on the season (interaction "position" and "time" $\mathrm{F}=1.99$; $P=0.059$ ), and the effect of the species tended to differ (interaction "species," "position" and "time"; $\mathrm{F}=1.60 ; P=0.08)$. Overall, soil below $C$. grandis and $T$. rose $a$ tended to hold a higher water content than soil in the open grassland at the peak of the rainy season (July), although no effect of G. ulmifolia was observed (Fig. 5a-c).

\section{Discussion}

Factors determining grassland ANPP in seasonally-dry silvopastoral systems

The temporal changes in grassland ANPP observed in this study follow the pattern found by Ospina et al. (2012) in open grasslands in the same area. ANPP is triggered at the onset of the rains, but declines at high levels of monthly rainfall. We observed that rainfall and soil moisture increased steadily from April to July, and that the decline in ANPP coincided with high amounts of rainfall, the highest percentage of ground cover and of graminoid standing biomass. Hence, neither water nor biomass appear to be limiting ANPP
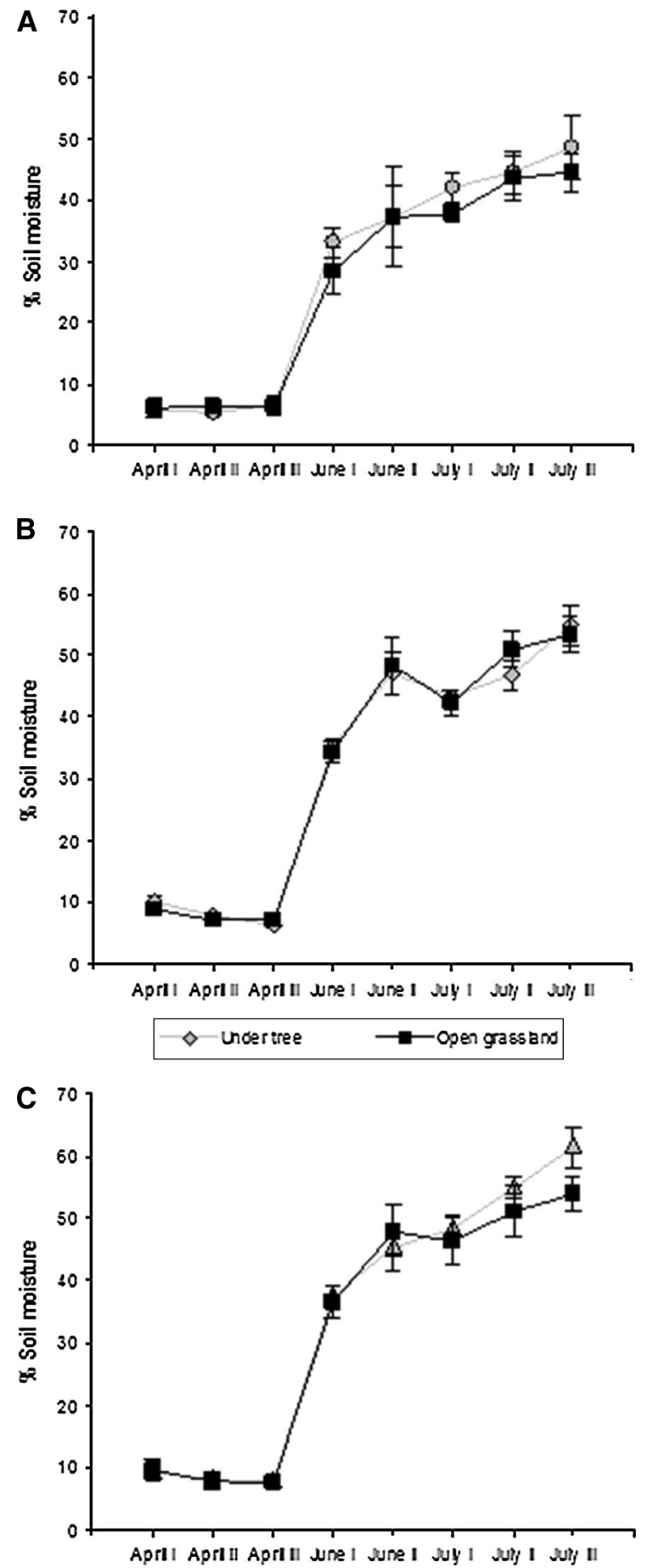

Fig. 5 Seasonal variation in soil moisture content $(\%$ in weight) in $C$. grandis (a, grey circles), G. ulmifolia (b, grey diamonds) and $T$. rosea (c, grey triangles). Black squares: Open grassland 
at the peak of the rainy season. Water logging, which occurs often in these soils with vertic properties, could be a reason for the reduction in ANPP at the peak of the rainy season.

\section{Effects of trees on grassland ANPP}

Trees interact with the understorey through shading, underground interactions and through effects on the soil. In our study, the trees generally had a negative effect on grassland ANPP, and this effect was related to the size of the tree crown, but not to the crown density. This result is supported by the finding of Sotelo Reyes (2012), who showed that crown diameter, but not crown density, significantly affects the amount of photosynthetic active radiation (PAR) that reaches the ground under isolated trees in these silvopastoral systems.

The effect of shading is also supported by the results on grassland composition. We found that the biomass of graminoids was lower below the trees than in the open grassland, whereas the cover of the forbs was slightly higher, two properties that can be related to the decline in light availability below the tree. Almost all grass species and all the dominant ones in these systems have a $\mathrm{C}_{4}$ photosynthetic pathway, which is characterized by a high light demand and a high tolerance to desiccation and high temperatures. By contrast, most of the forbs have a $\mathrm{C}_{3}$ metabolism, which is more effective with high humidity and also plants with $C_{3}$ metabolism tolerate better lower levels of irradiance, i.e. they have both lower light saturation and higher light compensation points (Forbes and Watson 1996). These results indicate that the net effect of the trees on grassland ANPP can be mediated by changes in the dominance of plant groups, thereby reinforcing the significance of light interception by the tree as a factor determining the outcome of the tree-grassland interaction in these systems. In addition, the effect of shading seems to outweigh the positive effect of the trees on soil carbon and cation content (Casals et al. 2013).

On the other hand, the effect of the trees on grassland ANPP appears to be unrelated to competition for water, as we detected no negative effects of trees on soil moisture in the upper soil in the dry season. Instead, the soil water content was higher below two of the tree species compared to the open grassland at the peak of the rainy season, which could reinforce water logging of the soils during this period, and could have contributed to the negative effects of the tree on grassland production. The observed higher water content in the soil could be the result of various processes such as the reduction of below-canopy temperature (Sotelo Reyes 2012) and evaporation (Olivero 2011), in addition to the fact that trees in these systems predominantly acquire water from intermediate and deep soil layers (Armas et al. unpublished data).

Seasonal changes in tree-grassland interactions

We hypothesized that the balance between facilitation and competition between trees and the grassland would change with the season (Kikvidze et al. 2006). More specifically, we expected that evergreen trees with dense crowns at the onset of the rains could have an ameliorating effect on evapotranspiration (Olivero 2011) when the water supply may be erratic, but we found no support for a switch from a predominantly facilitative interaction at the onset of the rains to a competitive interaction in the mid-wet season. The trees had negative effects on ANPP even in the dry season, and there was no correspondence between crown density and crown area and the effect of the tree on grassland ANPP in this period. One reason for the lack of facilitation of the tree on the grassland could be the relatively large capacity of water storage due to the high clay content of the soils in this area, which could buffer the effect of erratic rains at the onset of the rainy season.

The deciduous trees (T. rosea and G. ulmifolia), could have had a stronger negative effect on grassland ANPP than the evergreen tree since they supposedly have an "acquisitive" resource use strategy (Scholz et al. 2008), which corresponds to stronger competitive ability (Grime et al. 1997). This effect would have been particularly evident during the rainy season when the deciduous trees are active. However, our study indicates the opposite. The evergreen species $C$. grandis was the one with strongest negative effect on grassland ANPP, particularly at the production peak, an effect which appears to be related to the size of the tree and of the crown more than to the resource-use strategy.

\section{Conclusions}

The three tree species had a predominantly negative effect on grassland ANPP, with the highest reduction 
of ANPP at the peak of the rainy season, and with $C$. grandis, an evergreen species, having the largest negative effect. T. rosea, a deciduous tree species, had the least impact on grassland ANPP. These results indicate that the characteristics of the trees need to be considered when designing silvopastoral systems with the aim of minimizing undesirable effects on forage productivity. At the same time, the negative effects of the trees on the grassland take place at the peak of the production period when forage availability is probably not a bottleneck in these systems, which reinforces the significance of trees as providers of fodder (leaves, fruits) in the dry season when grassland productivity stops. The considerable reduction of grassland ANPP in these silvpastoral systems at the peak of the rainy season when standing biomass and ground cover are highest indicates the effect of an unknown limiting factor, which calls for further attention.

Acknowledgments This research has been co-funded by the Research Council of Norway, Environment 2015 Program and FRIMUF (Grants 204413 - SILPAS and 190134 - Multifunctional Landscapes) and by the European Commission, Directorate General for Research, within the 7th Framework Programme of RTD, Theme 2 - Biotechnology, Agriculture \& Food (Grant Agreement No. 227265 - FUNCiTREE). P. Casals is supported by a Ramón y Cajal Contract (Ministerio de Economía y Competitividad, Spain). We wish to thank the farmers in Muy Muy and Matiguás, who kindly facilitated access to the study sites, as well as Hamilton Núñez, Nestor Pineda and Amilcar Aguilar (CATIE, Nicaragua) for their assistance in the field. We thank two anonymous reviewers for many valuable comments on earlier versions of the manuscript.

Open Access This article is distributed under the terms of the Creative Commons Attribution License which permits any use, distribution, and reproduction in any medium, provided the original author(s) and the source are credited.

\section{References}

Armas C, Ordinales R, Pugnaire FI (2004) Measuring plant interactions: a new comparative index. Ecology 85:2682-2686

Bates D, Maechler M, Bolker B (2013) lme4: Linear mixedeffects models using S4 classes. R package version 0999999-2

Belsky AJ, Mwonga SM, Duxbury JM (1993) Effects of widely spaced trees and livestock grazing on understory environments in tropical savannas. Agrofor Syst 24:1-20

Bertness MD, Hacker SD (1994) Physical stress and positive associations among marsh plants. Am Nat 144:363-372
Casals P, Romero MJ, Rusch GM, Ibrahim M (2013) Soil organic $\mathrm{C}$ and nutrient contents under trees with different functional characteristics in seasonally dry tropical silvopastures. Plant and Soil 374:643-659

Cassel DK, Nielsen DR (1986) Field capacity and available water capacity. In: Klute A (ed) Methods of soil analysis. Part 1: physical and mineralogical methods. American Society of Agronomy Madison, Wisconsin, pp 901-926

Core Developing Team R (2009) R: a language and environment for statistical computing. R Foundation for Statistical Computing, Vienna

Delta-T Devices (2008) ML2x thetaprobe soil moisture sensor

Di Rienzo JA, Casanoves F, Balzarini MG, González L, Tablada M, Robledo CW (2012) InfoStat versión 2012. Grupo InfoStat, FCA, Universidad Nacional de Córdoba, Argentina

Dohn J, Dembele F, Karembe M, Moustakas A, Amevor KA, Hanan NP (2013) Tree effects on grass growth in savannas: competition, facilitation and the stress-gradient hypothesis. J Ecol 101:202-209

Espeleta JF, West JB, Donovan LA (2004) Species-specific patterns of hydraulic lift in co-occurring adult trees and grasses in a sandhill community. Oecologia 138:341-349

Fernández ME, Gyenge JE, Schlichter TK (2007) Balance of competitive and facilitative effects of exotic trees on a native Patagonian grass. Plant Ecol 188:67-76

Forbes JC, Watson RD (1996) Plants in agriculture, 2nd edn. Press Syndicate of the University of Cambridge, University Press, Cambridge

Grime JP, Thompson K, Hunt R, Hodgson JG, Cornelissen JHC, Rorison IH, Hendry GAF, Ashenden TW, Askew AP, Band SR, Booth RE, Bossard CC, Campbell BD, Cooper JEL, Davison AW, Gupta PL, Hall W, Hand DW, Hannah MA, Hillier SH, Hodkinson DJ, Jalili A, Liu Z, Mackey JML, Matthews N, Mowforth MA, Neal AM, Reader RJ, Reiling K, RossFraser W, Spencer RE, Sutton F, Tasker DE, Thorpe PC, Whitehouse J (1997) Integrated screening validates primary axes of specialisation in plants. Oikos 79:259-281

House JI, Archer S, Breshears DD, Scholes RJ (2003) Conundrums in mixed woody-herbaceous plant systems. J Biogeogr 30:1763-1777

ICRAF (2012) Agroforestry trees data base. Tabebuia rosea species description

INETER (2011) Boletines Meteorológicos. Managua, Nicaragua

Joffre R, Rambal S (1993) How tree cover influences the waterbalance of Mediterranean rangelands. Ecology 74:570-582

Kikvidze Z, Khetsuriani L, Kikodze D, Callaway RM (2006) Seasonal shifts in competition and facilitation in subalpine plant communities of the central Caucasus. J Veg Sci 17:77-82

Ludwig F, Dawson TE, Prins HHT, Berendse F, de Kroon H (2004) Below-ground competition between trees and grasses may overwhelm the facilitative effects of hydraulic lift. Ecol Lett 7:623-631

McCulloch CE (2006) Generalized linear mixed models. Statistical theory and methods. Encyclopedia of Envionmetrics

Nordenstahl M, Gundel PE, Clavijo MP, Jobbagy EG (2011) Forage production in natural and afforested grasslands of the Pampas: ecological complementarity and management opportunities. Agrofor Syst 83:201-211 
Olivero S (2011) Functional traits approach to assess the ecological processes of drought tolerance and water use efficiency in silvopastoral systems in Rivas Department, Nicaragua. Centro Agronómico Tropical de Investigación y Enseñanza (CATIE), Turrialba, p. 74

Ospina S, Rusch GM, Pezo DA, Casanoves F, Sinclair FL (2012) More stable productivity of semi natural grasslands than sown pastures in a seasonally dry climate. PLOS ONE. doi:10.1371/journal.pone.0035555

Pinheiro J, Bates D, DebRoy S, Sarkar D, Team tRDC (2013) nlme: linear and nonlinear mixed effects models. R package version $31-108$

Quesada F, Somarriba E, Malek M (2007) ShadeMotion

Sala OE, Austin AT (2000) Methods of estimating aboveground net primary productivity. In: Sala OE, Jackson RB, Mooney HA, Howarth RW (eds) Methods in ecosystem science. Springer, New York, pp 31-43
Scholes RJ, Archer SR (1997) Tree-grass interactions in savannas. Annu Rev Ecol Syst 28:517-544

Scholz FG, Bucci SJ, Goldstein G, Moreira MZ, Meinzer FC, Domec JC, Villalobos-Vega R, Franco AC, Miralles-Wilhelm F (2008) Biophysical and life-history determinants of hydraulic lift in Neotropical savanna trees. Funct Ecol 22:773-786

Sotelo Reyes M (2012) Efecto de las características y rasgos funcionales de los árboles en la intercepción y distribución de la radiación solar y la temperatura ambiental durante la época lluviosa en pasturas de Rivas, Nicaragua. Centro Agronómico Tropical de Investigación y Enseñanza (CATIE), Turrialba, p. 74

Stevens WD, Ulloa UC, Pool A, Montiel OM, Arbaláez AL, Cuatia DM (2001) Flora de Nicaragua, vol 1-3. Missouri Botanical Garden Press, Saint Louis 